\title{
Training and evaluation of professional competency in pediatric nursing: perspective of university professors*
}

\author{
Formação e avaliação da competência profissional em enfermagem \\ pediátrica: perspectiva de docentes universitários \\ Formación y evaluación de la competencia profesional en enfermería \\ pediátrica: perspectiva de docentes universitarios
}

How to cite this article:

Regino DSG, Nascimento JSG, Parada CMGL, Duarte MTC, Tonete VLP. Training and evaluation of professional competency in pediatric nursing: perspective of university professors. Rev Esc Enferm USP. 2019;53:e03454. DOI: http://dx.doi.org/10.1590/S1980-220X2018002703454

\section{Daniela da Silva Garcia Regino ${ }^{1}$ Juliana da Silva Garcia Nascimento² Cristina Maria Garcia de Lima Parada ${ }^{3}$ Marli Teresinha Cassamassimo Duarte ${ }^{3}$ Vera Lucia Pamplona Tonete ${ }^{3}$}

* Extracted from the dissertation: "Formação e avaliação de competência profissional em enfermagem pediátrica: perspectivas de docentes universitários", Universidade Estadual Paulista "Júlio de Mesquita Filho", 2018.

1 Centro Universitário Católico Salesiano Auxilium de Lins, Lins, SP, Brazil.

2 Faculdade de Uberaba, Uberaba, MG, Brazil.

3 Faculdade de Medicina de Botucatu da Universidade Paulista "Júlio de Mesquita Filho”, Botucatu, SP, Brazil.

\section{ABSTRACT}

Objective: To analyze the training and evaluation of professional competency to work in the area of pediatric nursing based on the conceptions and experiences of university professors. Method: A qualitative study conducted with pediatric nursing professors from six public undergraduate courses in the state of São Paulo, Brazil. The data were collected by semi-structured interview and analyzed by the Content Analysis method. Results: Sixteen professors participated. Five main themes emerged: competency definition, attributes to act with children, advances in the training of professional competency, challenges to enable training pediatric competency, and methods and instruments for evaluating competency acquisition to work in the area of pediatric nursing. Conclusion: The findings of this study point to the importance of a balanced approach in the cognitive, psychomotor and affective dimensions in training and evaluating professional competency in pediatric nursing, as well as extending the curricular valorization of this area of knowledge and practice.

\section{DESCRIPTORS}

Pediatric Nursing; Education, Nursing; Competency-Based Education; Educational Measurement. 


\section{INTRODUCTION}

With the scope of nursing currently being characterized by an increasingly complex society, professionals who are capable of acquiring and processing information, solving problems and making decisions through forming/learning competency which favor this perspective are necessary ${ }^{(1)}$.

In the process of teaching and learning which enables forming/training this profile of professional competency, it is understood that the nursing teacher should expand their involvement in the educational field. And, from a critical posture about teaching, they should consider and relate the various changes which occur in both teaching practice and in nursing, as well as respecting students in their autonomy as agents of their own learning ${ }^{(2)}$.

On the other hand, what has been observed is that nursing teachers adopt the way they experienced their own training in their teaching practices as a reflection of a traditional vertical and uncritical education process, supported in the transmission of previously established knowledge, disregarding the different dimensions of professional competency to be formed ${ }^{(3)}$. And also valuing evaluation systems which are only aimed at quantifying this knowledge retained by the student ${ }^{(4)}$.

As an alternative to overcome the traditional models of professional training in health, it is proposed to be guided by dialogical competence. Through an integrative and active approach to the teaching-learning process, this type of training seeks to promote students' meaningful learning, by weighing both the scientific standards of knowledge and skills as to the singularities of work situations and of the subjects involved in the educational action, re-signifying values and attitudes, such as: flexibility, creativity, teamwork, involvement, ethics and social responsibility ${ }^{(5)}$.

The restlessness caused by the dichotomy of what is desired in training and evaluating professional competency in nursing and what is actually experienced ${ }^{(6)}$ can extend to the universe of teaching in pediatric nursing, especially when the aim is to develop the necessary competency for comprehensive child care $^{(7)}$.

Despite advances in educational policies, practices and existing scientific knowledge in the area of pediatric nursing, it is assumed that training and evaluating the acquisition of competency to perform it are still based on the traditional model, not considering approaches using different dimensions of the competency to be acquired.

Therefore, the importance of this research is justified, aiming to analyze the training and evaluation of professional competency to act in the area of pediatric nursing, based on the conceptions and experiences of university professors with a view to obtaining subsidies to contribute to the necessary critical and coherent training, and transforming the reality of Brazilian childhood.

\section{METHOD}

\section{StUdi DESIGN}

This is a qualitative study ${ }^{(8)}$.

\section{SCENARIO}

The study participants included 16 professors from six public institutions of undergraduate nursing courses who train pediatric nursing students. There are currently 13 public nursing undergraduate courses in the state of São Paulo, Brazil, but there were no professors involved from seven of them, either because they did not agree to participate or due to the lack of conditions of their institutions for research. It is also noteworthy that the number of participants in this study was defined when sufficiency of the collected material was detected to reach the established objective. Thus, it was decided to constitute an intentional sample of those who could contribute, in quantity and intensity, with pertinent information to the various dimensions of the phenomenon under study, seeking to contemplate convergences and divergences on the conceptions and experiences to be studied ${ }^{(9)}$.

\section{Data collection}

Data were collected through recorded semi-structured interviews conducted from May to December of 2016, following a previously specified script with guiding questions ${ }^{(8)}$ aimed at characterizing the participants and to meet the objectives based on the following proposition: discourse about the teaching process for developing professional competency to act in pediatric nursing.

After clarifying the research objectives to the participants, the interviews were previously scheduled via Skype for spoken and visual communication in real time, and recorded by the Free Video Call Recorder for Skype, according to the availability of each participant, without interfering in the institutional progress. We chose this data collection strategy due to the physical distance between the municipalities of residence of the researcher and the institutions of the interviewees. The interview time was approximately 40 minutes. It should be noted that the interviewer was one of the authors who is a nurse with a Master's degree in child health, a Doctorate in nursing in progress at the time, as well as a professor in undergraduate nursing and who already had a consistent experience in this type of data collection. The researcher passed on the recording to the participants at the end of each interview so that they could comment or correct them, thus validating their statements.

\section{DATA ANALYSIS AND PROCESSING}

Analysis of the obtained material was based on the principles of qualitative data interpretation, called Content Analysis, and a Thematic Analysis was performed from among these Content Analysis aspects ${ }^{(8)}$. The three steps for operationalizing the qualitative data were followed with contribution from three of the authors, as follows: after transcription of the full statements, a floating reading was performed in the first stage (Preanalysis), both vertically (each statement) and horizontally (between the statements), seeking to raise hypotheses about the object under study. In the second stage (Material Exploration), the thematic categories were defined and the registration units (meaning units corresponding to content clippings of the statements, 
taken as base units, aiming at categorization) and the context units were identified in the documents (central meanings to encode the registration units in order to understand the exact meanings) (Chart 1 ).

An inferential interpretation was performed in the third stage (Data Processing and Interpretation) through intuition, reflexive and critical analysis, especially searching for the latent content in the statements ${ }^{(8)}$ by analyzing them based on the assumptions of professional competency formation according to Philippe Perrenoud ${ }^{(2-5)}$ and the comprehensiveness of child care ${ }^{(6)}$.

\section{ETHICAL ASPECTS}

This study was approved by the local Research Ethics Committee, fulfilling the requirements of Resolution no. 466/12 of the National Health Council, which regulates the norms for conducting research involving human beings, under Opinion no. 1.526.327. An Informed Consent Form was sent to the participants by mail and signed on two copies, one of which was returned to the researcher by mail. The participants' statements, when presented, are characterized by the letter D, plus the interview number (D1 to D16) and the letters A to F, corresponding to their institution.

\section{RESULTS}

Sixteen (16) professors from the total of 42 professors in the pediatric nursing area from the six selected public undergraduate courses participated in the study. All participants were female, ranging in age from 34 to 53 years old. The shortest time in undergraduate teaching was 15 years and the longest was 37 years. Regarding the accomplishment of post-graduation courses, the majority had a title of doctor. The working time in the current institution ranged from two to 28 years, and the time in the pediatric area ranged from two to 28 years.

The analysis of the statements collected from the teachers enables systematizing five thematic categories with their respective context units (central meanings), as presented in Chart 1, with examples of registration units (statement clippings).

Chart 1 - List of thematic categories, context units and recording units obtained from the analysis of the statements.

\begin{tabular}{|c|c|c|}
\hline Thematic Categories & Contextual Units & Registration Units \\
\hline \multirow[t]{2}{*}{$\begin{array}{l}\text { Definition of professional } \\
\text { competency }\end{array}$} & $\begin{array}{l}\text { Set of knowledge, skills and attitudes } \\
\text { to perform work with excellence }\end{array}$ & $\begin{array}{l}\text { I define competence as a set of essential knowledge, skills and attitudes for } \\
\text { professional nurses to perform their profession and have an efficient and effective } \\
\text { practice (D2F). }\end{array}$ \\
\hline & $\begin{array}{l}\text { There should be a balanced } \\
\text { appreciation of knowledge, know- } \\
\text { how and know-what during training }\end{array}$ & $\begin{array}{l}\text { I think that training takes place through three elements: knowledge, know-how } \\
\text { and know-what. This triad needs to be worked on, one can not possess just one } \\
\text { and find that they have succeeded in forming competency (D10E). }\end{array}$ \\
\hline \multirow[t]{8}{*}{$\begin{array}{l}\text { Attributes to work with } \\
\text { children }\end{array}$} & $\begin{array}{l}\text { Know the different phases of child } \\
\text { development }\end{array}$ & $\begin{array}{l}\text { I think it is imperative to address the developmental stages of the child as } \\
\text { programmatic content. The student must theoretically understand how a child } \\
\text { develops, the peculiarities, the important/concerning events in each stage } \\
\text { theoretically before experiencing the practice (D3F). }\end{array}$ \\
\hline & $\begin{array}{l}\text { List of factors that influence the } \\
\text { health process of childhood illness }\end{array}$ & $\begin{array}{l}\text { I understand that it is necessary to have knowledge about the factors that influence } \\
\text { the health/illness process of the child and to consider them in exercising the } \\
\text { profession in practical actions with the health team, effectuating this content for } \\
\text { students in nursing (D7E). }\end{array}$ \\
\hline & $\begin{array}{l}\text { Performing child and family-centered } \\
\text { care }\end{array}$ & $\begin{array}{l}\text { It is necessary to work on the theoretical foundation centered on the child and } \\
\text { their family. This is the current concept, as we know that there are three types of } \\
\text { focus for pediatric care: disease-centered care, child-centered care, and child and } \\
\text { family-centered care, with the latter being the theoretical framework that we must } \\
\text { adopt (D4D). }\end{array}$ \\
\hline & $\begin{array}{l}\text { Adopting the systematization of } \\
\text { nursing care oriented to the needs } \\
\text { of the child and their family was } \\
\text { indicated }\end{array}$ & $\begin{array}{l}\text { The nurse must provide systematized care to the child, focusing on satisfying their } \\
\text { biopsychosocial needs in an organized way through instruments, prioritizing all } \\
\text { levels of care for the child and their family (D2B). }\end{array}$ \\
\hline & $\begin{array}{l}\text { Know how to welcome/receive and } \\
\text { communicate with the child and } \\
\text { their family }\end{array}$ & $\begin{array}{l}\text { It is important to make the student proficient in approaching and welcoming/ } \\
\text { receiving the child and their family through theoretical and practical knowledge. } \\
\text { Thus, they will not suffer in this context when faced with the experiences that they } \\
\text { have to deal with in the future (D4D). }\end{array}$ \\
\hline & $\begin{array}{l}\text { Perform specific technical } \\
\text { procedures for pediatric nursing }\end{array}$ & $\begin{array}{l}\text { I believe that it becomes a danger to not have the technical ability to provide child } \\
\text { care in everything, but especially in hospital care, in airway management, catheter } \\
\text { IV devices, breastfeeding management and feeding. We need to put responsibility } \\
\text { on the teacher to enable students to be able to perform procedures (D9B). }\end{array}$ \\
\hline & $\begin{array}{l}\text { To know the public policies focused } \\
\text { on comprehensive child health care }\end{array}$ & $\begin{array}{l}\text { I believe that the student must have knowledge about the public policies directed } \\
\text { at children, which base and prioritize expanded health care, setting a critical and } \\
\text { reflective view of the importance of comprehensiveness present in the guidelines } \\
\text { of these policies as the main guiding axis (D1B). }\end{array}$ \\
\hline & $\begin{array}{l}\text { Caring for children at all levels of } \\
\text { health care }\end{array}$ & $\begin{array}{l}\text { I think that nursing students should have contact with healthy children, experience } \\
\text { healthy children and look at them in the scope of comprehensiveness, in the scope } \\
\text { of promotion, and not only from an aspect of an already present disease (D8C). }\end{array}$ \\
\hline
\end{tabular}


...continuation

\begin{tabular}{|c|c|c|}
\hline Thematic Categories & Contextual Units & Registration Units \\
\hline \multirow[t]{3}{*}{$\begin{array}{l}\text { Advances in professional } \\
\text { competency training in } \\
\text { pediatric nursing }\end{array}$} & $\begin{array}{l}\text { Partnership established between the } \\
\text { fields of practice and educational } \\
\text { institutions }\end{array}$ & $\begin{array}{l}\text { Look, even though there is a need for ability on the part of the university to make } \\
\text { suitable practice fields feasible for the students, we have the facility, since there } \\
\text { are openings and reception by day cares, city hall and hospital, and that makes } \\
\text { all the difference in the teaching and learning process (D5E). }\end{array}$ \\
\hline & $\begin{array}{l}\text { Curricular organization that } \\
\text { gradually addresses teaching primary } \\
\text { health care up until the hospital }\end{array}$ & $\begin{array}{l}\text { The students in the first and second years are enrolled in Primary Care, the third } \\
\text { year is all hospital, and in the fourth year it is half/half so they can understand } \\
\text { public policies and actions to promote health and prevention, in order to learn } \\
\text { how to work with sick children, as it should be (D6A). }\end{array}$ \\
\hline & $\begin{array}{l}\text { Institution is open for discussions } \\
\text { and curricular changes }\end{array}$ & $\begin{array}{l}\text { I say that for one of the facilities to work, thinking from the perspective of } \\
\text { training and the evaluation of competency, is the willingness of the educational } \\
\text { institution to reflect on the curriculum all the time, giving this freedom, proposing } \\
\text { discussion, changes and courses for the teachers (D7E). }\end{array}$ \\
\hline \multirow[t]{3}{*}{$\begin{array}{l}\text { Challenges for professional } \\
\text { competency training in } \\
\text { pediatric nursing }\end{array}$} & $\begin{array}{l}\text { Theoretical and practical hours } \\
\text { reduced for teaching pediatric } \\
\text { nursing, with late insertion of the } \\
\text { student in contact with children }\end{array}$ & $\begin{array}{l}\text { The greatest difficulty for molding competency regarding the care of children } \\
\text { in the nursing graduate is the fact that they are not inserted into activities with } \\
\text { children and their families in the first year. It's late, this insertion could be much } \\
\text { earlier. This is a flaw, a curricular gap, also characterized by a short time of } \\
\text { theory, a short time of practice, which devalues their academic gaze into the } \\
\text { universe of children (D2F). }\end{array}$ \\
\hline & $\begin{array}{l}\text { Lack of integration of the disciplines } \\
\text { in forming competency in pediatric } \\
\text { nursing }\end{array}$ & $\begin{array}{l}\text { We work exclusively with our discipline, without articulation with the other } \\
\text { disciplines. The thought in this way is fragmented and the student, alone, nor always } \\
\text { succeed in the calls you need establish and your critical thinking is impaired (D8C). }\end{array}$ \\
\hline & $\begin{array}{l}\text { Difficulty in adapting students to } \\
\text { active teaching methodologies }\end{array}$ & $\begin{array}{l}\text { Despite our efforts, we still cannot accomplish the active methodology all the } \\
\text { time. Especially due to the resistance of the students themselves, some groups } \\
\text { are expecting an expository dialogue class, they want the content ready, spit } \\
\text { out, they want rote education. Do you think that nowadays, just because } \\
\text { of technology, the students are very different than those from the past? In } \\
\text { their aspirations and in the way they want things? You fool yourself and feel } \\
\text { disappointed (D15E). }\end{array}$ \\
\hline \multirow[t]{2}{*}{$\begin{array}{l}\text { Evaluating acquiring } \\
\text { competency to perform in } \\
\text { pediatric nursing }\end{array}$} & $\begin{array}{l}\text { Verification of the student's ability } \\
\text { to identify and solve childrens' } \\
\text { problems through problematization }\end{array}$ & $\begin{array}{l}\text { I evaluate competency acquisition by the ability to use problematization, solving } \\
\text { problems and situations that mimic real life, or real life itself, by using their } \\
\text { knowledge, skills and attitudes. For me, this is a well-founded criterion to ensure } \\
\text { that, in fact, there was ideal training of child care competency (D9B). }\end{array}$ \\
\hline & $\begin{array}{l}\text { Use of different instruments to } \\
\text { monitor student evolution in } \\
\text { acquiring knowledge, skills and } \\
\text { attitudes }\end{array}$ & $\begin{array}{l}\text { People are very involved in evaluating knowledge, skills and attitudes, using } \\
\text { different activities such as practices, simulations, case studies and seminars, self- } \\
\text { assessment, their attitudes in structuring their portfolio, and their attitudes during } \\
\text { practical evaluations, this only removes the traditional evaluations (D5E). }\end{array}$ \\
\hline
\end{tabular}

\section{DISCUSSION}

The objective of this research was to analyze the training and evaluation of professional competency in pediatric nursing from the perspective of directly involved professors.

The findings of the present study point to approaching the definition of professional competency presented by the professors with that of Phillipe Perrenoud. For this author, competency is characterized by the ability to act successfully in facing the situations that present themselves, necessitating the support of a set of knowledge, but not restricted to it. In applying knowledge to practice, it is essential that you also access skills and attitudes that, when integrated, enable the professional to do, reflect and evaluate ${ }^{(2)}$.

Despite this approach, the attributes pertinent to nurses to act with children presented by teachers were basically related to knowledge and skills, with little or no allude to attitudes, distancing themselves from the definition of dialogical competency ${ }^{(5)}$.

Knowing the peculiarities of the different phases of child development is essential for composing competency in pediatric nursing, delimiting childhood as a phase of potentialities and vulnerabilities that requires such knowledge ${ }^{(10)}$.

In this same perspective, knowledge about the vulnerabilities to diseases and illnesses of each phase and the ways to avoid them and to treat them when present is one of the great pillars of performance in pediatric nursing, and there is great theoretical and practical knowledge production inherent in nursing itself and other health areas in order to subsidize child care in such situations. However, the importance of conceiving teaching care in an expanded way is highlighted in the current scientific production of pediatric nursing, taking into account the possibilities of comprehensive care, which also includes health promotion ${ }^{(7,10)}$.

In coherence with learning comprehensive care, the professors emphasized the importance of the child-centered and family-centered approach to care. It is understood that teaching child care, previously based on pathology, over time has included the child and their family as the best and ideal care model, which justifies the need to work on this attribute to make the student able to offer appropriate care ${ }^{(11)}$.

Nursing care systematization was also identified as an essential attribute for forming competency in childcare. At present, there is a lack of consensus about the data that must be collected by the nurse to generate information and subsidize clinical decision-making, constituting a factor of concern when it is recognized that effective implementation of nursing care systematization leads to improvement in care quality and helps in elaborating protocols which are effective in pediatric nursing practice ${ }^{(12)}$.

Adherence to nursing care systematization as an attribute is aligned with the need to obtain knowledge to receive and 
communicate effectively with children and families; an aspect that has been a challenge for daily care, explicitly expressing conflicts between families and the nursing care team ${ }^{(13)}$. Thus, it is hoped that teaching will prioritize development of interpersonal and foster relationship skills, developing the necessary empathy and responsibility of nurses in this aspect ${ }^{(14-15)}$.

Another attribute linked to competency in pediatric nursing indicated by the professors was the performance of techniques and procedures specific to this age group. This attribute has historically been associated with the work of pediatric nurses; however, there is the current recognition that humanized and safe approaches should be considered to lessen the possible traumas resulting from such techniques and procedures, in addition to the technical and scientific competencies necessary for their performance ${ }^{(16)}$.

In the scope of the nursing care directed to the collective, the professors valued comprehensiveness by highlighting knowledge of public policies by the nurse as a pertinent attribute in working with children. The twentieth century marked significant advances in terms of children, in the perspective of conceiving them in their entirety as a developing subject and with needs and rights to be respected, adding formulations, projects, programs and policies in favor of Brazilian children. These changes culminated in publication of the National Policy for Comprehensive Health Care for Children in 2015, which includes the synthesis of these official documents ${ }^{(17)}$.

In corroborating the proposals inserted in public policies aimed at children, the importance of care at all levels of health was emphasized as an attribute, restricting purely hospital-centered thinking, which only values the disease and not the individual ${ }^{(18)}$.

According to the above statements, it is conceived that teaching based only on the hospital-centered model, disregards the need for training the practice of health promotion and disease prevention for children, while the integration between theory and practice for developing competency in vocational training in the different practice scenarios favors general professional training, which in addition to this practice, includes training for interventions in the most different situations of the health/disease process.

Regarding the advances in forming professional competency in pediatric nursing, the existing partnership between the practice and teaching fields refers to the idea of prioritizing practical experiences for training, including what is ideal for work, and not in the sense of something distant, but as something that is created in a joint project between the partners. Thus, the importance of the student to know the reality, to contextualize the practical field, to propose intervention plans and to meet the individual and social demands of everyday life is revealed; a construction which is only possible through effective partnership between teaching and learning institutions and health practice ${ }^{(7,19)}$.

The organization of the curriculum from primary care to the hospital gradually enables the formation of competency, which emerged as an advance in this study, making it possible to approach comprehensiveness of health promotion, prevention and recovery actions, as previously discussed. Such actions should be developed so that the student can intervene in health problems at different levels, living conditions and in risks and damages to health ${ }^{(20)}$. Another important achievement in forming professional competency in the pediatric area as indicated by the teachers was the institution being open for curricular discussion with joint elaboration of methodologies that propitiate critical thinking. Critical thinking is a fundamental skill for the development of health professionals, and has the same value as that attributed to technical skills ${ }^{(5)}$.

Contrary to the advances in forming professional competency in the area under study, the professors explained the challenges to develop it; among them, the theoretical and practical workload made available to the teaching directed to children and their care, which was reported as insufficient. This shows the value that nursing courses have given to the other age groups of human development, to the detriment of pediatrics. Although nursing curricula have incorporated transformations and advances in the pediatric area since its implantation as a compulsory discipline in the curricula of Brazilian nursing, there is also the need to strengthen and optimize the distribution of their approach during the nursing training course, to mobilize the search and integration of new knowledge, skills and attitudes, thereby guaranteeing competent professional performance ${ }^{(7)}$.

The curricular gap regarding the workload given to the pediatric nursing approach confirms the challenge for late insertion of the student into contact with children during their training, even in facing the need to approach it in their professional reality as early as possible, which would provide conditions for meaningful and consistent learning in developing competency in this area ${ }^{(2)}$.

Disarticulation among the disciplines in the undergraduate nursing course, which was also suggested by the professors as a challenge to be overcome, reinforces the idea that in addition to a more equitable and gradual distribution of the workload in favor of pediatric nursing education, it is also necessary to modify the fragmented teaching which prioritizes little articulation between knowledge, separating the disciplines between theoretical and practical blocks, which therefore compromises apprehension of the comprehensive care perspective in training nurses ${ }^{(2,7)}$.

Another challenge to be overcome (as pointed out by the professors) is the difficulty of adapting nursing students to active teaching methods for forming professional competency in pediatrics in order to overcome traditional education, which induces the student from the very early age to passively receive content to be learned through the teacher-student transmission ${ }^{(21)}$.

In this process, teacher reflection as educators is recommended in facing students' denial and resistance to transformative, critical and reflexive education, which adopts active teaching-learning methodologies, rethinking how the active method should be approached and applied in the search for new results and adherence to this innovative teaching ${ }^{(22)}$.

Understanding that training teachers is generally focused on conventional teaching methods, it is necessary to train them in association with inductive governmental policies in order to extend the practice of this active methodology $y^{(23)}$. 
In line with the need to include the active teaching methodology, the participants pointed out which strategies enabled training, and linked to them was an evaluation of competency acquisition in pediatric nursing to be adopted.

Verification of students' ability to identify and solve children's problems through problematization was highlighted. This has been considered an active teaching methodology, which makes it possible to evaluate students' theoretical and practical learning. This method consists of providing undergraduates with action-reflection-action activities on fundamental aspects of professional practice and distances them from exclusively traditional forms of evaluation that do not cover all aspects necessary for forming competency ${ }^{(24)}$.

The use of different strategies, which enables monitoring student evolution in acquiring knowledge, skills and attitudes was also highlighted. When used together, the theoretical evaluations and self-assessments, clinical laboratory simulations, case study presentations, seminars and portfolios enable evaluating the dimensions of professional competency by the students, and their active and co-responsible participation in both the evaluation process and in forming competency for pediatric care.

Finally, despite its regional coverage, it is important to note that the findings of this research bring important subsidies to support reflections on teaching-learning processes developed in the area in focus for national and international undergraduate nursing courses, which are committed to training professionals who will make a difference in the production and defense of children's health.

\section{CONCLUSION}

The analysis of the participants' perspective regarding the definitions of professional competency and the attributes pertinent to the nurse to work with children presents important aspects to be considered in the formation professional competency in this area. However, it also demonstrates the prioritization of cognitive and procedural dimensions, devalorizing the attitudinal dimension, that is, the development of affective aspects, the specific challenges and nuances involved in this assistance, which should not be underestimated.

The highlighted advances corroborate inserting reflexive processes in the educational institutions to provide transformative actions, which ensure valuing curriculum for teaching pediatric nursing. Especially, with the increase of the workload and the gradual and integrated approach to the other related curricular components, combined with the adoption of teaching strategies and evaluation that include the student as active participant and co-responsible for his or her professional competence.

We suggest that new research be carried out to verify the attributes mentioned herein, verifying the impact of teaching-learning processes in the context of professional practice.

\section{RESUMO}

Objetivo: Analisar a formação e a avaliação de competência profissional para atuar na área de enfermagem pediátrica, a partir das concepções e experiências de docentes universitários. Método: Estudo de cunho qualitativo, realizado com docentes de enfermagem pediátrica de seis cursos de graduação públicos do estado de São Paulo, Brasil. Os dados foram coletados por entrevista semiestruturada e analisados pelo método de Análise de Conteúdo. Resultados: Participaram 16 docentes. Emergiram cinco principais temas: definição de competência, atributos para atuar com crianças, avanços na formação de competência profissional, desafios para viabilizar a formação de competência pediátrica e métodos e instrumentos para a avaliação da aquisição de competência para atuar na área de enfermagem pediátrica. Conclusão: Os achados deste estudo apontam a importância da abordagem equilibrada das dimensões cognitivas, psicomotoras e afetivas na formação e avaliação da competência profissional em enfermagem pediátrica, como também a ampliação da valorização curricular desta área de conhecimento e prática.

\section{DESCRITORES}

Enfermagem Pediátrica; Educação em Enfermagem; Educação Baseada em Competências; Avaliação Educacional.

\section{RESUMEN}

Objetivo: Analizar la formación y evaluación de la competencia profesional para actuar en el área de enfermería pediátrica, desde las concepciones y experiencias de docentes universitarios. Método: Estudio de cuño cualitativo, realizado con docentes de enfermería pediátrica de seis carreras universitarias públicas del Estado de São Paulo, Brasil. Se recogieron los datos mediante entrevista semiestructurada y estos fueron analizados por el método de Análisis de Contenido. Resultados: Participaron 16 docentes. Surgieron cinco temas principales: definición de competencia, atributos para actuar con niños, avances en la formación de competencia profesional, retos para viabilizar la formación de competencia pediátrica y métodos e instrumentos para la evaluación de la adquisición de competencia para actuar en el área de enfermería pediátrica. Conclusión: Los hallazgos de este estudio señalan la importancia del abordaje equilibrado de las dimensiones cognitivas, psicomotoras y afectivas en la formación y evaluación de la competencia profesional en enfermería pediátrica, así como la ampliación de la valorización curricular de esta área de conocimiento y práctica.

\section{DESCRIPTORES}

Enfermería Pediátrica; Educación en Enfermería; Educación Basada en Competencias; Evaluación Educacional.

\section{REFERENCES}

1. Itatani T, Nagata K, Yanagihara K, Tabuchi N. Content analysis of student essays after attending a problem-based learning course: facilitating the development of critical thinking and communication skills in japanese nursing students. Healthcare (Basel). 2017;5(3): E47. DOI: 10.3390/healthcare5030047

2. Oliveira SNO, Bernardi MC, Prado MLP, Lazzari DD, Lino MM, Vicensi MC. Professores de enfermagem e o desenvolvimento de competências: reflexões sobre a teoria de Philippe Perrenoud. Rev Enferm UFSM. 2015;5(3):589-96 
3. Lopes RE, Silva AC, Nóbrega-Therrien SM. Formação reflexiva no ensino da enfermagem: discussão à luz de Schön. Cad Pes. 2015;22(1):4758. DOI: http://dx.doi.org/10.18764/2178-2229.v22.n1.p.47-58

4. Cardoso D, Santos E, Cardoso ML, Oliveira CR, Rodrigues MA, Apóstolo J. Instruments for measuring undergraduate nursing students' knowledge, attitudes and skills in evidence-based practice: a systematic review protocol. JBI Database System Rev Implement Rep. 2017;15(8):1979-1986. DOI: 10.11124/JBISRIR-2016-003218

5. Chirelli MQ, Pio DAM, Soares MOM. Competência dialógica: avaliação do desempenho no currículo integrado. Indagatio Didactica [Internet]. 2016 [citado 2018 mar. 14];8(3):109-23. Disponível em: http://revistas.ua.pt/index.php/ID/article/view/4380/3956

6. Rangel RF, Backes DS, Ilha S, Siqueira HCH, Martins FDP, Zamberlan C. Comprehensive care: meanings for teachers and nursing students. Rev Rene [Internet]. 2017 [citado 2018 mar. 14];18(1):43-50. Disponível em: http://www.periodicos.ufc.br/rene/article/ viewFile/18866/29599

7. Cursino EG, Fujimori E, Gaíva MA. Comprehensiveness in child healthcare teaching in undergraduate nursing: perspective of teachers. Rev Esc Enferm USP. 2014;48(1):110-7. DOI: 10.1590/S0080-623420140000100014

8. Minayo MCS. O desafio do conhecimento: pesquisa qualitativa em saúde. São Paulo: Hucitec; 2014

9. Minayo MCS. Sampling and saturation in qualitative research: consensuses and controversies. Rev Pesq Qualit [Internet] 2017 [cited 2018 Mar 15];5(7):1-12. Available from: http://rpq.revista.sepq.org.br/index.php/rpq/article/view/82/59

10. Silva DI, Chiesa AM, Veríssimo MLOR, Mazza VA. Vulnerability of children in adverse situations to their development: proposed analytical matrix. Rev Esc Enferm USP. 2013;47(6):1397-1402. DOI: 10.1590/S0080-623420130000600021

11. Onishi JYT, Ribeiro CA, Silva MCFCRD, Borba RIH. Technical nursing students interacting with family members of hospitalized children. Rev Bras Enferm. 2017;70(6):1137-44. DOI: 10.1590/0034-7167-2016-0374

12. Lima AP, Chianca TC, Tannure MC. Assessment of nursing care using indicators generated by software. Rev Latino Am Enfermagem 2015;23(2):234-41. DOI: 10.1590/0104-1169.0177.2547

13. Hill C, Knafl KA, Santacroce SJ. Family-centered care from the perspective of parents of children cared for in a pediatric intensive care unit: an integrative review. J Pediatr Nurs. 2017;pii:S0882-5963(17)30531-6. DOI: 10.1016/j.pedn.2017.11.007

14. Khajeh M, Dehghan Nayeri N, Bahramnezhad F, Sadat Hoseini AS. Family centered care of hospitalized children: a hybrid concept analysis in Iran. Health Promot Perspect. 2017;7(4):210-5. DOI: 10.15171/hpp.2017.3

15. Hashimoto H. Effects of a support program on nurses' communication with hospitalized children's families. Compr Child Adolesc Nurs. 2017;40(3):173-87. DOI: 10.1080/24694193.2017.1307473

16. Malmström B, Nohlert E, Ewald U, Widarsson M. Simulation-based team training improved the self-assessed ability of physicians, nurses and midwives to perform neonatal resuscitation. Acta Paediatr. 2017;106(8):1273-9. DOI: 10.1111/apa.13861

17. Brasil. Ministério da Saúde. Portaria n. 1.130/MS, de 5 agosto de 2015. Institui a Política Nacional de Atenção Integral à Saúde da Criança (PNAISC) no âmbito do Sistema Único de Saúde (SUS) [Internet]. Brasília; 2015 [citado 2018 mar. 14]. Disponível em: http://bvsms.saude. gov.br/bvs/saudelegis/gm/2015/prt1130_05_08_2015.html

18. Pina JC, Moraes SA, Furtado MC, Mello DF. Presence and extent of the primary health care attributes among children hospitalized for pneumonia. Rev Latino Am Enfermagem. 2015;23(3):512-9. DOI: 10.1590/0104-1169.0502.2582

19. Romaniuk D, Chu S, D'Annunzio D, Garvey G. A health care-academic partnership: developing pediatric nursing education. J Contin Educ Nurs. 2017;48(12):557-62. DOI: 10.3928/00220124-20171115-07

20. Viegas SM, Penna CM. Integrality: life principle and right to health. Invest Educ Enferm. 2015;33(2):237-47. DOI: 10.1590/S012053072015000200006

21. Sayyah M, Shirbandi K, Saki-Malehi A, Rahim F. Use of a problem-based learning teaching model for undergraduate medical and nursing education: a systematic review and meta-analysis. Adv Med Educ Pract. 2017;8:691-700. DOI: 10.2147/AMEP.S143694

22. Gal B, Rubio M, Iglesias E, González P. Evaluation of participatory teaching methods in undergraduate medical students' learning along the first academic courses. PLoS One. 2018;13(1):e0190173. DOI: 10.1371/journal.pone.0190173.

23. Christofoletti G, Fernandes JM, Martins AS, Oliveira Junior SA, Carregaro RL, Toledo AM. Grau de satisfação discente frente à utilização de métodos ativos de aprendizagem em uma disciplina de ética em saúde. Rev Educ [Internet]. 2014 [citado 2018 mar. 14];8(2):188-97. Disponível em: http://www.reveduc.ufscar.br/index.php/reveduc/article/viewFile/823/334

24. Cadorin L, Bressan V, Palese. A. Instruments evaluating the self-directed learning abilities among nursing students and nurses: a systematic review of psychometric properties. BMC Med Educ. 2017;17(1):229. DOI: 10.1186/s12909-017-1072-3 